\title{
ANTINEOPLASTIC AGENTS USED IN PEDIATRIC HEMATOPOIETIC BONE MARROW TRANSPLANTATION: A REVIEW ABOUT PHARMACOLOGY AND PHARMACEUTICAL ISSUES
}

\author{
Rodrigo Spineli Macedo ${ }^{1}$, Ana Carolina Sayuri Nagai ${ }^{2}$, Ananda Vial Cobello ${ }^{3}$, Haíssa Pereira Ramos
} Rodrigues ${ }^{4}$, Larissa Maria Hilsdorf Bernardi Barreto ${ }^{5}$

\begin{abstract}
1 Master in Sciences - Universidade Federal de São Paulo, 2 Oncology Pharmacist - Pharmacy Division - Beneficência Portuguesa Mirante, 3 Oncology Pharmacist - Clinical Pharmacy Assistence - Beneficência Portuguesa Mirante, 2 Oncology Pharmacist - Pharmacy Division of Universidade Federal de São Paulo, 5 Board Certified Oncology Pharmacy - Sociedade Brasileira de Farmacêuticos em Oncologia
\end{abstract}

Correspondence to: larissamhbb@gmail.com

\begin{abstract}
This article proposes the characterization of the main chemotherapeutic agents used in hematopoietic stem cell transplantation in pediatric patients, carrying out a review of the main pharmacological and pharmacokinetic characteristics that are peculiar to children, as well as technical aspects for the handling, prescription, and administration of each one of these.

It is extremely important that all professionals know how to recognize the characteristics of each drug and how its peculiarities impact the quality of patient's treatment, being able to predict and propose necessary interventions for potential problems of therapy, which can be identified and measured.
\end{abstract}

Keywords: Chemotherapy. Chemotherapeutic agents. Bone Marrow Transplantation. Pediatrics.

\section{INTRODUCTION}

The indication for hematopoietic stem cell transplantation (HSCT) in pediatrics presents peculiarities, since there are a greater number of indications in non-malignant diseases and a greater chance of cure in hematological neoplasms, thus making it possible to carry out many combinations of chemotherapeutic agents for the elaboration of protocols. Moreover, the pharmacokinetics of chemotherapeutic agents may differ from the way they occur in adults.

In this scenario, studies reported and going on in the Pediatric Pharmacology using these drugs should be highlighted, since important differences are observed in comparison to adults in their pharmacodynamics and pharmacokinetics. Important aspects of the pharmacology of these agents in children are related in pharmacokinetics aspects, which have a greater impact on distribution and metabolism phases than on absorption and excretion phases.

The absorption phase of the drug can suffer significative changes if administered per oral once the drug passes through the mouth, stomach or intestinal absorption, which can be affected by gastrointestinal motility, gastric $\mathrm{pH}$ and conveyors. ${ }^{2}$ For instance, in oral absorption, we evaluate changes in development phase, mainly related to: acid secretion, gastrointestinal motility and biliary secretion. Usually, these changes are smaller at birth and after 6 or 8 months of life, thus, it may interfere in the reduction or delay of absorption. ${ }^{2}$ In distribution phase, which the most of chemotherapeutic agents are already available, factors such as aqueous or lipid components, plasma proteins and carriers are essential for evaluation during developmental changes phase. 
The amount of extracellular fluid is greater at birth and with the arrival of youth, this factor is reduced, causing a greater distribution volume in children (smaller concentration peaks); the protein binding rate is also lower at birth but increases significantly up to 1-2 years of age; the permeability of the bloodbrain barrier is much higher at birth, so that after 3 years of age, this barrier permeability is already similar to adults.

After distribution there is a metabolism phase, usually in the liver, going through two enzyme phases. Phase I enzymes such as CYP450 (CYP3A4, 2D6, $2 \mathrm{C} 8 / 9 . .$.$) are in smaller quantities at birth and they$ increase to adult levels during childhood and youth, while phase II enzymes, such as glucuronides, glutathione, sulfates, and acetates reach levels compared to adults after 6 months of life. ${ }^{2,3}$

In the excretion phase, in which the kidney is the main drug excreting organ, the maturation of this organ begins in the embryo and is completed in childhood. Glomerular filtration rates reach adult values between 6 months to 1 year old. In general, it was observed expressive changes in children and youth with pre-existing comorbidity which can increase the risks of toxicity. ${ }^{4}$

Chemotherapy drugs often have a narrow therapeutic window and combined with a large variability between drug plasma concentrations observed in pediatric oncology patients, this can result in suboptimal therapy or increased toxicity.

In clinical practice, physiologic characteristics, pharmacokinetics profile, and rational drug prescription are decisive for the success of the transplant.

To help physicians, pharmacists and nurses to perform the best therapy for the patient, it is described below the main chemotherapeutic agents used in mobilization and conditioning protocols. This discussion includes granulocyte colony-stimulating factor Filgrastim (G-CSF), with description of clinical, pharmacodynamic and pharmacokinetic aspects, emetogenic potential and recommended dose adjustments for renal or hepatic toxicity. In order to demonstrate clearly and objectively, technical aspects such as compatibilities, concentration, irritant potentials, needed care in administration, as well as guidance and drug characteristics for handling are compiled in a table (see Table 1), organized based on their alphabetical names.

\section{ALKYLATING AGENTS}

\subsection{Busulfan}

It is a bifunctional alkylating agent, that has a mechanism of action based on the release of methanesulfonate groups, producing carbon ions which can insert an alkyl group in the DNA strand. It is used in conditioning regimens in association with other drugs, such as melphalan, cyclophosphamide and fludarabine. ${ }^{6,7}$

The volume of distribution $(\mathrm{Vd})$ ranges between 0.62 and $0.85 \mathrm{~L} / \mathrm{kg}$. It is mainly metabolized in the liver. About $30 \%$ of the administered dose is excreted in the urine over 48 hours with $1 \%$ of the drug in unchanged form.

When administered orally, the bioavailability of busulfan is quite variable, so there is a preference for the intravenous route. Busulfan clearance is related to age (the higher the age, the lower the clearance) and weight (the higher the weight, the lower the clearance). For patients older than 18 years, clearance ranged from 2.64 to $2.9 \mathrm{~mL} / \mathrm{min} / \mathrm{kg}$. For children aged from 2 to 14 years, it ranged from 4,4 to $4.5 \mathrm{~mL} / \mathrm{min} / \mathrm{kg}$ and for children aged 3 years or less, clearance ranged from 6,8 to $8.4 \mathrm{~mL} / \mathrm{min} / \mathrm{kg}$.

Busulfan has moderate to high emetogenic potential (>30-90\% emesis frequency) at doses used in the conditioning regimen. They can cause epileptic seizures, which can occur up to 24 hours after the last dose of busulfan, due to their high lipid solubility and low level of protein binding. Thus, the prophylactic use of anticonvulsants is indicated for at least 12 hours before the first dose of busulfan, and for at least 24 hours after the last dose infusion. The most used drug for prophylaxis is phenytoin, but caution is needed in its administration because phenytoin increases busulfan clearance by $\geq 15 \%$. If alternative anticonvulsants are used, busulfan clearance may be decreased and dosing should be monitored accordingly. ${ }^{8}$

For both intravenous and oral administration, it is recommended to monitor the serum level of busulfan to reach the desired levels (concentration between 200 to $600 \mathrm{ng} / \mathrm{mL}$ ), thus avoiding possible toxicities. Busulfan doses can be adjusted according to serum level (according to protocol and disease). ${ }^{6}$

An adverse effect often associated with busulfan conditioning regimens is Sinusoidal Obstruction Syndrome (SOS). It usually occurs within the first 30 
days of transplantation, with an incidence of 5 to $40 \%$ in pediatric patients. ${ }^{9}$ For treatment, defibrotide is usually used in adults and children. The use of acetaminophen should be avoided due to the risk of SOS. ${ }^{8,9}$

There are no cases in literature about dose adjustment to renal or hepatic impairment.

\subsection{Carmustine}

Alkylating agent from nitrosourea family, their cytotoxic action is mediated by the inhibition of enzymatic processes involved in DNA formation. This drug also causes a break in DNA strands and, consequently, processes in the synthesis of DNA, RNA, and proteins were changed. It has a $\mathrm{Vd}$ of $3.25 \mathrm{~L} / \mathrm{kg}$ and liver metabolism (not specified). Their excretion is mostly renal (60\% to $70 \%)$, but it can also be excreted through the respiratory (6 to $10 \%$ ) and fecal (1\%) routes. Their elimination half-life is of 22 minutes (1.4 minutes in the primary phase and 17.8 minutes in the secondary phase), and the emetogenic potential ranges from high (when $>250 \mathrm{mg} / \mathrm{m} 2$ ) to moderate (when $<250 \mathrm{mg} / \mathrm{m} 2$ ). It is used in autologous HSCT in the conditioning phase in myeloablative schemes, such as BEAM and BEAC.

\subsection{Cyclophosphamide}

Cyclophosphamide is an alkylating agent of the oxazaphosphorine class. With activation in the liver based on two cytotoxic metabolites: phospharamide mustard and acrolein, knowing as a pro-drug. Their antineoplastic activity is linked only to phospharamide, which binds to the DNA of the tumor cell, which in turn, does not interrupt the production of RNA and proteins. Therefore, an imbalance occurs, leading the tumor cell to death. Despite they have not an antineoplastic effect, acrolein is responsible for the urotoxic side effects of cyclophosphamide, treated prophylactically with mesna (65 to $100 \%$ of the cyclophosphamide dose) for uroprotection. 10,11,12

Constant hydration is also essential, to help the stimulate bladder emptying at regular intervals, and their administration should be avoided at night to prevent urinary retention and increase the amount of toxic active metabolites that would remain in the bladder for longer. It is also important to monitor urinary sediments that may be signs of urotoxicity or nephrotoxicity. ${ }^{13}$

It has moderate emetogenic potential for doses less than or equal to $1500 \mathrm{mg} / \mathrm{m} 2$ and high emetogen- ic potential for doses greater than $1500 \mathrm{mg} / \mathrm{m} 2$, so the use of antiemetics is recommended. Stomatitis and mucositis can also be manifested with the use of protocols containing cyclophosphamide. 8 Their plasma concentration varies according to the dose administered. The peak concentrations are 4, 50 and $500 \mathrm{nmol} / \mathrm{mL}$ after administration of 1 to $2 \mathrm{mg} / \mathrm{kg}$ (Peters et al, 1989), 6 to $15 \mathrm{mg} / \mathrm{kg}$ (Klein et al, 1980) and $60 \mathrm{mg} / \mathrm{kg}$ (Jardine et al, 1978), respectively. 10,11,12

A delay in cyclophosphamide metabolization may occur in patients with liver failure. Importantly, it is a drug that crosses the placental barrier and is detectable in breast milk and cerebrospinal fluid. It is mainly excreted by the kidneys and it is indicated to change the dose in cases of renal failure. It has a halflife of approximately 7 hours in adults and 4 hours in children, with peak levels of alkylation occurring within about 2 to 3 hours of drug administration. For cases where creatinine clearance is less than 10 $\mathrm{mL} /$ minute, administer $100 \%$ of the dose, and if it is greater than or equal to $10 \mathrm{~mL} /$ minute, adjust to $75 \%$ of the initial dose. ${ }^{8}$

\subsection{Melphalan}

Alkylating agent that inhibits DNA and RNA synthesis via interstrand croos-liking with DNA, biding at the N7 position of guanine.

It is a mechlorethamine derivative that stops the DNA replication process, leading to cell death. High dosage melphalan treatment is associated with side effects such as oral mucositis. To reduce the incidence of these side effects, it is recommended pre and post melphalan cryotherapy for patients who will receive high doses of the drug, which can also be performed with ice cubes. In addition, a high volume of hydration is recommended to avoid precipitation of melphalan in the renal tubules. ${ }^{13}$

Regarding pharmacokinetics, their $V d$ is $0.5 \mathrm{~L} / \mathrm{kg}$, and it binds to plasma proteins, mainly to albumin (55$60 \%)$. It has limited penetration of the blood-brain barrier and its excretion is fecal (20-50\%) and renal (10\%). Melphalan is not a dialyzable drug. Its elimination half-life is of 90 minutes, so the drug infusion should not pass this period. It has a high emetogenic potential (at doses $>140 \mathrm{mg} / \mathrm{m} 2$ ) and moderate (at doses < equal $140 \mathrm{mg} / \mathrm{m} 2)^{10}$

At autologous stem cell transplant, if the serum creatinine was up then $2 \mathrm{mg} / \mathrm{dL}$, a reduction of up to $30 \%$ of the programmed initial dose is recommended. ${ }^{8}$ 


\subsection{Thiotepa}

Thiotepa is a stable aziridinium compound that has activity in initial and metabolite forms, thiotepa (triethylenethiophosphoramide) triethylenephosphoramide (TEPA), respectively. it has activity against some solid tumors but, today it is reserved for some specific cases of conditioning with high doses of chemotherapy in HSCT. Their mechanism of action consists of the protonation of the nitrogen of the aziridinium group, leading to its instability and causing a consequent nucleophilic cross attack on the DNA strands. ${ }^{14}$

In pediatric HSCT doses vary between $125 \mathrm{mg} / \mathrm{m} 2$ and $350 \mathrm{mg} / \mathrm{m} 2$ in 2 to 3 subsequent days of infusion (autologous and allogeneic) and should not exceed the maximum cumulative dose of $1050 \mathrm{mg} / \mathrm{m} 2$ or 42 $\mathrm{mg} / \mathrm{kg}{ }^{15}$

The plasma half-life varies between the two active forms, taking from 03 to 21 hours. Excretion is performed by both the kidneys and liver. It does not require dose adjustment in renal and hepatic dysfunctions (however, the risks must be less than the clinical benefits, and its use is contraindicated in severe insufficiencies) and these characteristics occur in the same way in adults and children..$^{14,16}$

This drug can cause mucositis, SOS, hepatotoxicity, neurotoxicity and pneumonitis. It has a dose-dependent emetogenic potential (moderate at doses $<300$ $\mathrm{mg} / \mathrm{m} 2$; high at doses $\geq 300 \mathrm{mg} / \mathrm{m} 2)^{.16}$

The use of thiotepa may be contraindicated with existing renal or hepatic impairment and should be limited to cases where benefit outweighs risk. ${ }^{8}$

\section{ANTIMETABOLITES}

\subsection{Methotrexate}

It belongs to the class of folate antagonists, acting at three different sites: inhibiting of dihydrofolate reductase (DHFR) and thymidylate synthase and altering reduced folate transportation. At low doses, it is used as prophylaxis for graft versus host disease (GVHD) due to its immunosuppressive activity, probably because of to the inhibition of lymphocyte multiplication. ${ }^{17}$

The usual dose for children aged two years or older is of 8 to $15 \mathrm{mg} / \mathrm{m}^{2}$ intravenously on D1, followed by 8 to $10 \mathrm{mg} / \mathrm{m}^{2}$ intravenously on D3, D6 and D1 1 after HSCT. $^{18}$

For the handling of small doses used in protocols for GVHD prophylaxis, it is recommended to use the commercial presentation of $25 \mathrm{mg} / \mathrm{mL}$, thus obtaining a slightly larger volume for administration. ${ }^{18}$

The Vd is approximately 0.4 to $0.8 \mathrm{~L} / \mathrm{kg}(40 \%$ to $80 \%$ of body weight). About $50 \%$ of the administered dose is bound to plasma proteins. The main route of elimination is renal, with $80 \%$ to $90 \%$ of the dose being excreted in the urine within 24 hours of administration. Biliary excretion is $10 \%$ or less. Half-life for low doses is of 0.7 to 5.8 hours. $^{18}$

Methotrexate is metabolized by oxidation, its main drug interactions occur by reducing renal clearance, thus increasing exposure to the drug and its possible toxicities. ${ }^{19}$ It has low emetogenic risk. ${ }^{20}$

\subsection{Cytarabine}

It is an antimetabolite, cytosine analogue, a pyrimidine nucleotide. Their main mechanism of action occurs through the inhibition of DNA polymerase by competition with deoxycytidine triphosphate, causing the inhibition of DNA synthesis. It is a cycle-specific drug that acts in the $S$ phase, and it can also block the progression of the cell cycle from the G1 phase to $S$ phase. Its toxicity is dependent on both the drug concentration and the time of exposure. Its main cytotoxic effects are due to drug incorporation into DNA and RNA chains. ${ }^{21}$

Cytarabine is used in myeloablative conditioning. Its emetogenic risk is dose-related, with a dose of $75 \mathrm{mg} / \mathrm{m}^{2}$ having moderate risk and doses above $3000 \mathrm{mg} / \mathrm{m}^{2}$ presenting high risk. ${ }^{15}$

The drug is $13 \%$ bounded to plasma protein. It is metabolized in the liver by deoxycytidine kinase and other nucleotide kinases to the active metabolite, aracytidine triphosphate. About $86 \%$ to $96 \%$ of the dose is metabolized as inactivated form, uracil arabinoside. ${ }^{15}$ It is also metabolized, in a small proportion, in the kidneys, gastrointestinal mucosa, granulocytes, and other tissues that contain the enzyme cytidine deaminase..$^{21}$

Initial elimination half-life is from 7 to 20 minutes and the final one is from 1 to 3 hours. About $80 \%$ of the administered dose is renally excreted, and $90 \%$ is converted in inactive form within 24 hours. $^{15}$

Some guidelines have been used by clinicians, with dosing adjustment in renal impairment only in highdose cytarabine ( $\geq 2000 \mathrm{mg} / \mathrm{m} 2 /$ dose) for serum creatinine $1.5-1.9 \mathrm{mg} / \mathrm{dL}$ or increase of $0.5-1.2 \mathrm{mg} / \mathrm{dL}$, reducing dose to $1000 \mathrm{mg} / \mathrm{m} 2 /$ dose $^{8}$

Dosing adjustment for hepatic impairment is recommended to patients with liver failure since cytarabine 
is partially detoxified in the liver. The recommendation of authors such as Floyd, 2006 is to reduce the dose by $50 \%$ for any increase in transaminases, and subsequent doses can be increased in the absence of toxicity.

\subsection{Fludarabine}

It is a fluorinating nucleotide analogue to antiviral agent vidarabine. It is a water-soluble prodrug that is converted to the active 2-fluoro-ara-ATP by the enzyme deoxycytidine kinase. This metabolite competitively inhibits DNA synthesis through the inhibition of DNA polymerase, ribonucleotide reductase, DNA primase, and DNA ligase. Its action occurs mainly in the $S$ phase of the cell cycle..$^{15,22}$

It is used in conditioning regimen for reduced-intensity allogeneic transplantation with a dose limited to $30 \mathrm{mg} / \mathrm{m}^{2}$, once a day, for 6 doses. It can be used in combination with busulfan and thymoglobulin for hematologic malignancies or in association with busulfan and alemtuzumab in myeloid neoplasms and in non-malignant diseases. It has minimal emetogenic potential. ${ }^{23}$

Fludarabine $\mathrm{Vd}$ is of $83-98 \mathrm{~L} / \mathrm{m}^{2}$. The active metabolite is quickly and totally dephosphorylated in plas$\mathrm{ma}$ to the inactive metabolite, 2-fluoro-ara-A. The elimination half-life is of 10.5 to 19 hours. About 40 to $60 \%$ is excreted in the urine, with $23 \%$ as 2 -fluoro-vidarabine within 24 hours. Renal elimination is dose dependent, being of $24 \%$ at doses of $25 \mathrm{mg} / \mathrm{m}^{2} /$ day and reaching $40-60 \%$ at high doses. Drug clearance is $79 \mathrm{~mL} / \mathrm{min} / \mathrm{m}^{2} .{ }^{15}$

Adjustment of the dose for renal impairment in infants, children and youth is recommended if the glomerular filtration rate (GFR) is between $30-50 \mathrm{~mL} /$ minute $/ 1.73 \mathrm{~m} 2$, opting for the administration of $80 \%$ of the dose and if GFR $<30 \mathrm{~mL} /$ minute $/ 1.73 \mathrm{~m} 2$ is not recommended. ${ }^{8}$

\section{Epipodophyllotoxins - Etoposide}

It is a semi-synthetic derivative from podophyllotoxin, a plant product with antimitotic action. It inhibits DNA topoisomerase II, thus interrupting DNA synthesis by binding to the DNA-enzyme complex, preventing enzyme repair and consequently propagating strand breaks. Through the action of p53, these strand breaks signal the interruption of the cell cycle and when there are many, induce apoptosis. It mainly affects the $S$ and $G 2$ phases of the cell cycle..$^{24,25}$

Their Vd is of 5 to $10 \mathrm{~L} / \mathrm{m}^{2}$ and its binding to plasma proteins is $94 \%$ to $98 \%$. It is metabolized by liver, via CYP3A3 and $3 A 5$, generating several metabolites. Its terminal half-life is of 6 to 8 hours, considering normal liver and kidney functions. About $55 \%$ is eliminated by urine as unchanged form within 24 hours. ${ }^{26,27}$

Adjustment of the dose for renal impairment in infants, children and adolescents is recommended if the glomerular filtration rate (GFR) is between 10 - 50 $\mathrm{mL} /$ minute/ $1.73 \mathrm{~m} 2$, opting for the administration of $75 \%$ of the dose and if GFR $<10 \mathrm{~mL} /$ minute/1.73m2, opting for the administration of $50 \%$ of the dose. ${ }^{8}$

In hepatic impairment, administer $50 \%$ of dose if bilirubin between $1.5-3 \mathrm{mg} / \mathrm{dL}$ or AST > 3 times, and $25 \%$ of dose if bilirubin $>3 \mathrm{mg} / \mathrm{d} / \mathrm{L} .{ }^{8}$

In allogeneic conditioning protocol for acute lymphoid leukemia, it is used in association with fludarabine and busulfan from 6 months of age, at a dose of $20 \mathrm{mg} / \mathrm{Kg} .18 \mathrm{It}$ has low emetogenic potential. ${ }^{26}$

\section{Biological products}

Some agents from biological origin can be used both in HSCT conditioning regimens for the prevention of GVHD and in support of myelosuppression arising from therapy with cytotoxic drugs that induce myeloablation. In the specific case of alemtuzumab and antithymocyte immunoglobulin (rabbit), the main activity of these agents consists of inducing an immune response against tumor cells. Regarding supportive drugs from biological origin, they act by stimulating the production of progenitors of hematopoietic stem cells so that they can act in protection against microorganisms.

\subsection{Alemtuzumab}

Alemtuzumab is a humanized anti-CD52 monoclonal antibody developed for the treatment of lymphoproliferative disorders such as chronic lymphocytic leukemia, non-Hodgkin's lymphoma, and prevention of GVHD. It binds to CD52, a glycoprotein contained in more than $95 \%$ of lymphocytes, macrophages, monocytes, among others (but not in granulocytes, red blood cells, platelets and hematopoietic stem cells), leading to the immune system response through ADCC-type effector mechanisms (antibody-dependent cellular cytotoxicity) and CDC (complement-dependent cytolysis). ${ }^{31}$

The elimination half-life varies according to administration periods and manufacturer (around 11 hours after the first dose of Campath ${ }^{\oplus} ; 6$ days after the last dose of Campath ${ }^{\circledast}$; around 2 weeks for Lemtrada ${ }^{\circledR}$ ). Clearance decreases after repeated doses due to 
decreased CD52 receptors in peripheral blood. No need for adjustments due to kidney and liver failure. Furthermore, like most monoclonal antibodies, it has minimal emetogenic potential. ${ }^{15}$

\subsection{Antithymocyte globulin (rabbit)}

Antithymocyte globulin (ATG) is used in T lymphocyte depletion as a GVHD prevention strategy in both myeloablative conditioning regimens and reduced-intensity conditioning in allogeneic HSCT. It has several formulations based on the sensitization of horses, goats and rabbits, the latter being preferable for use in this scenario. ${ }^{32}$

Their mechanism of action consists mainly in the depletion of T lymphocytes but, it also decreases B lymphocytes, Natural Killer cells and dendritic cells when administered in high doses. The proposed mechanisms of action induce cell depletion through mechanisms of ADCC, CDC, B cell apoptosis and modulation of key surface molecules such as adhesion receptors and chemokines. ${ }^{33}$

It can lead to hypersensitivity and anaphylaxis reactions, requiring premedication with corticosteroids, paracetamol, and antihistamines.15 Besides that, it can induce cytomegalovirus (CMV) reactivation, requiring prophylaxis in HIV-positive patients. It can reactivate Epstein Barr virus as well and, in these cases, the physician should evaluate the use of rituximab for PTLD (post-transplantation lymphoproliferative disease) prevention. ${ }^{32,15}$

With regard of their pharmacokinetics, it can vary between adults and children. Seidel et al. demonstrated that the half-life of ATG can be constant and with a linear correlation between doses of $7.5-20$ $\mathrm{mg} / \mathrm{kg}$ and $\mathrm{Cmax}$, and that at high doses body accumulation of ATG may occur. ${ }^{34}$

Van Der Zilde et al. in turn, have demonstrated that ATG levels can be decreased in children due to development of anti-ATG antibodies, increasing the risk of acute GVHD. ${ }^{35}$

It does not need dose adjustment in renal or hepatic dysfunctions and has very low emetogenic potential. ${ }^{15}$

\subsection{Filgrastim}

Colony stimulating factors are used to mobilize hematopoietic stem cells from the bone marrow to the periphery, facilitating their collection for later transplantation. In addition, they are used in post-conditioning phase to promote bone marrow recovery. Among many agents in this class, we highlight filgrastim. ${ }^{8}$

Filgrastim (or G-CSF - granulocyte colony-stimulating factor) is an $18.8 \mathrm{kDa}$ glycoprotein encoded by a single gene present on chromosome 17. It is produced by macrophages, monocytes, endothelial cells, among others, and generates a stimulus response from the activation of the JAK-STAT signaling pathway. ${ }^{36}$ The pharmacokinetics of filgrastim indicates onset of action between 1 and 2 days after administration and normalization of neutrophil count within 4 days of use. It has a high $V d(150 \mathrm{~mL} / \mathrm{Kg})$, but no evidence of accumulation in intravenous administration. Bioavailability is around $60 \%$ and the elimination half-life in neonates is of 4.4 hours. It does not require adjustments in liver and renal failure, except in cases of filgrastim-induced glomerulonephritis, and has no emetogenic potential. The main adverse reactions of filgrastim are fever, thrombocytopenia, and bone pain. ${ }^{15}$ 
TABLE 1-Technical aspects (Drugs in alphabetical order) $8,15,17,18,21,22,23,24,26,27,28,29,30,37$

\begin{tabular}{|c|c|c|c|c|}
\hline Dosage form & Compatibility & Stability & Extravasation risk & Guidances \\
\hline $\begin{array}{c}\text { Antithymocyte globulin } \\
\text { (rabbit) } \\
\text { Ampoule vial } 25 \mathrm{mg}\end{array}$ & NS or D5W & Used immediately & - & $\begin{array}{l}\text { Required the use of } \\
0.2 \text {-micron inline filter. } \\
\text { Reconstitute with } 5 \mathrm{~mL} \\
\text { of water for injection to } \\
\text { a final concentration of } \\
5 \mathrm{mg} / \mathrm{mL} \text {. }\end{array}$ \\
\hline $\begin{array}{c}\text { Alemtuzumab } \\
\text { Ampoule vial } 30 \mathrm{mg} / 1 \mathrm{~mL}\end{array}$ & $\begin{array}{l}\text { Dilute for infusion in } 100 \\
\mathrm{~mL} \text { NS or D5W }\end{array}$ & $\begin{array}{c}8 \text { hours }\left(15^{\circ}-25^{\circ} \mathrm{C}\right) \text { or } 8 \\
\text { hours }\left(2^{\circ}-8^{\circ} \mathrm{C}\right)\end{array}$ & - & $\begin{array}{l}\text { Gently invert the bag to } \\
\text { mix the solution. } \\
\text { Do not shake the } \\
\text { preparation prior to use. }\end{array}$ \\
\hline $\begin{array}{l}\text { Bussulfan } \\
\text { Ampoule vial } 6 \mathrm{mg}+10 \mathrm{~mL} \\
\text { of diluent }-10 \mathrm{mg} / \mathrm{mL}\end{array}$ & $\begin{array}{c}\text { NS or D5W to a final } \\
\text { concentration of } \geq 0.5 \\
\mathrm{mg} / \mathrm{mL}\end{array}$ & $\begin{array}{c}8 \text { hours }\left(15^{\circ}-25^{\circ} \mathrm{C}\right) * \text { or } 12 \\
\text { hours }\left(2^{\circ}-8^{\circ} \mathrm{C}\right)+3 \text { hours } \\
\left(15^{\circ}-25^{\circ} \mathrm{C}\right)^{*}\end{array}$ & May be an irritant & $\begin{array}{l}\text { Diluent volume should } \\
\text { be } 10 \text { times the volume } \\
\text { of bussulfan. } \\
\text { *including infusion time. }\end{array}$ \\
\hline $\begin{array}{l}\text { Carmustine Ampoule vial } \\
100 \mathrm{mg}+\text { diluent (ethanol } \\
3 \mathrm{~mL}+27 \mathrm{~mL} \text { water for } \\
\text { injection) }\end{array}$ & NS or D5W & $\begin{array}{l}24 \text { hours }\left(2^{\circ}-8^{\circ} \mathrm{C}\right)+6 \\
\text { hours }\left(15^{\circ}-25^{\circ} \mathrm{C}\right)^{*} \\
\text { or } 3 \text { hours }\left(15^{\circ}-25^{\circ} \mathrm{C}\right)^{*}\end{array}$ & May be an irritant & $\begin{array}{l}\text { Incompatible with DEHP; } \\
\text { protect from ligth; final } \\
\text { concentration of } 0,2-1 \\
\mathrm{mg} / \mathrm{mL} \text {; infusion over } 1-2 \\
\text { hours. } \\
\text { *including infusion time }\end{array}$ \\
\hline $\begin{array}{c}\text { Cyclophosphamide } \\
\text { Ampoule vial of } 200 \mathrm{mg} \text { or } \\
1000 \mathrm{mg}\end{array}$ & NS or D5W & 24 hours $\left(15^{\circ}-25^{\circ} \mathrm{C}\right)$ & May be an irritant & $\begin{array}{c}\text { Urotoxic agente, } \\
\text { recommended } \\
\text { prophylaxis with Mesna. } \\
\text { Reconstitute with water } \\
\text { for injections to a final } \\
\text { concentration of } 20 \mathrm{mg} / \\
\mathrm{mL} .\end{array}$ \\
\hline $\begin{array}{c}\text { Cytarabine } \\
\text { Ampoule vial } 100 \mathrm{mg} / \mathrm{mL} \text { or } \\
500 \mathrm{mg} / \mathrm{mL}\end{array}$ & $\begin{array}{l}\text { NS, D5W or Ringer } \\
\text { lactato }\end{array}$ & 48 hours $\left(15^{\circ}-25^{\circ} \mathrm{C}\right)$ & - & - \\
\hline $\begin{array}{c}\text { Etoposide } \\
\text { Ampoule vial } 20 \mathrm{mg} / \mathrm{mL}\end{array}$ & NS or D5W & $\begin{array}{c}0.2 \mathrm{mg} / \mathrm{mL}: 96 \text { hours } \\
\left(2^{\circ}-8^{\circ} \mathrm{C}\right) \text { or } 0.4 \mathrm{mg} / \mathrm{mL}: 24 \\
\text { hours }\left(2^{\circ}-8^{\circ} \mathrm{C}\right)\end{array}$ & Irritant & $\begin{array}{c}\text { Incidence of } \\
\text { precipitation increases } \\
\text { with final concentration } \\
>0.4 \mathrm{mg} / \mathrm{mL} . \\
\text { Incompatible with DEHP } \\
\text { material. }\end{array}$ \\
\hline $\begin{array}{l}\text { Filgrastim } \\
\text { Ampoule vial } 300 \mathrm{mcg} / 1 \mathrm{~mL} \\
\text { or prefilled syringe of } 300 \\
\mathrm{mcg} / 1 \mathrm{~mL} \text { (in this latter the } \\
\text { volume cannot be handled). }\end{array}$ & D5W & $\begin{array}{c}24 \text { hours }\left(15^{\circ}-25^{\circ} \mathrm{C}\right) \text { or } 48 \\
\text { hours }\left(2^{\circ}-8^{\circ} \mathrm{C}\right)\end{array}$ & - & $\begin{array}{l}\text { It can be administered } \\
\text { Subcutaneously or } \\
\text { Intravenously, in this } \\
\text { latter solution for } \\
\text { administration should } \\
\text { not exceed a final } \\
\text { concentration of } 15 \mathrm{mcg} / \\
\mathrm{mL} \text {, due to the risk of } \\
\text { adsorption of the drug } \\
\text { into the plastic syringe. }\end{array}$ \\
\hline $\begin{array}{c}\text { Fludarabine } \\
\text { Ampoule vial } 50 \mathrm{mg}\end{array}$ & NS or D5W & $\begin{array}{l}48 \text { hours }\left(15^{\circ}-25^{\circ} \mathrm{C}\right) \text { or } \\
\left(2^{\circ}-8^{\circ} \mathrm{C}\right)\end{array}$ & - & $\begin{array}{c}\text { Reconstitute with } 2 \mathrm{~mL} \\
\text { of water for injection to a } \\
\text { final concentration of } 25 \\
\mathrm{mg} / \mathrm{mL} .\end{array}$ \\
\hline
\end{tabular}




\begin{tabular}{|c|c|c|c|c|}
\hline $\begin{array}{c}\text { Melphalan } \\
\text { Ampoule vial } 6 \mathrm{mg}+\text { Diluent } \\
10 \mathrm{~mL}-6 \mathrm{mg} / \mathrm{mL}\end{array}$ & NS or D5W & $\begin{array}{l}8 \text { hours }\left(15^{\circ}-25^{\circ} \mathrm{C}\right)^{*} \text { or } \\
12 \text { hours }\left(2^{\circ} \mathrm{C} \text { a } 8^{\circ} \mathrm{C}\right)+3 \\
\text { hours }\left(20^{\circ} \mathrm{C} \pm 5^{\circ} \mathrm{C}\right)^{*}\end{array}$ & May be an irritant & $\begin{array}{l}\text { Concentration range } \\
\geq 0,5 \mathrm{mg} / \mathrm{mL} \text {; Infusion } \\
\text { volume can be up } 10 \\
\text { times the volume of } \\
\text { Bussulfan. } \\
\text { *including infusion time }\end{array}$ \\
\hline $\begin{array}{c}\text { Methotrexate } \\
\text { Ampoule vial } 25 \mathrm{mg} / \mathrm{mL} \text { or } \\
100 \mathrm{mg} / \mathrm{mL}\end{array}$ & NS or D5W & 24 hours $\left(15^{\circ}-25^{\circ} \mathrm{C}\right)^{*}$ & - & *including infusion time \\
\hline $\begin{array}{l}\text { Thiotepa } \\
\text { Ampoule vial } 15 \mathrm{mg} \\
\text { or } 100 \mathrm{mg} \text {, should be } \\
\text { reconstituted with water for } \\
\text { injection obtaining a final } \\
\text { concentration of } 10 \mathrm{mg} / \mathrm{mL}\end{array}$ & NS or D5W & $\begin{array}{c}8 \text { hours }\left(15^{\circ}-25^{\circ} \mathrm{C}\right)^{*} \text { or } 24 \\
\text { hours }\left(2^{\circ}-8^{\circ} \mathrm{C}\right)+8 \text { hours } \\
\left(15^{\circ}-25^{\circ} \mathrm{C}\right)^{*}\end{array}$ & & $\begin{array}{c}\text { In pediatrics, final } \\
\text { dilution volume must } \\
\text { allow finl concentration } \\
\text { between } 0,5 \text { and } 1 \mathrm{mg} / \\
\mathrm{mL} \text {; Infusion time over } \\
2-4 \text { hours; Mandatory the } \\
\text { use of } 0.2 \text {-micron inline } \\
\text { filter. } \\
\text { *including infusion time }\end{array}$ \\
\hline
\end{tabular}

NS: Normal saline; D5W: 5\% dextrose in water; DEHP: Di-(2-ethylhexyl) phthalate (Used in plastic bags to provide malleability); Vd: Volume of distribution.

\section{CONCLUSION}

The pharmacologic profile of the drugs contributed to the elaboration of a safety recommendations list of each one. The safe use of drugs in HSCT will help in guide and systematize the main actions of the drugs in therapeutic process, helping minimize the risk of errors and ensure an effective treatment, increasing patient's safety.

Knowledge of pharmacological therapy is essential for clinical practice, as it provides support for possible drug-related reactions and presents necessary interventions for potential problems arising from the therapy, which can be identified and measured.

\section{CONFLICTS OF INTEREST}

There are no known conflicts of interest associated with this publication.

\section{ACKNOWLEDGMENTS}

We thanks Juliana Cancino Bernardi for proofreading the text. 


\section{REFERENCES}

1. Gonzales CQF. Pharmacology in the pediatric patient. Revista medica clinica las condes [Internet]. 2016 [cited 2021 Jun 9]; - 2016; 27(5) 652659. Avaiable from: https://www.elsevier.es/ es-revista-revista-medica-clinica-las-condes-20 2-pdf-S0716864016300918 doi: 10.1016/j.rmcIc.2016.09.010.

2. Inaba H, Diouf B. Basic Knowledge of Chemotherapy in Children [Internet]. Memphis: Cure4kids; 2013 Apr [cited 2021Jun 9]. Avaiable from: https://www.cure4kids.org/private/lectures/ppt2970/zip_C4K-2948-0MX-Fundamental-Chemo.zip/story.html

3. Koren G, Schechter T. Cancer chemotherapy in young children: Challenges and solutions. Pediatric Blood and Cancer [Internet]. 2007 [cited 2021 Jun 9];49(S7):1091-1092. Avaiable from: https://doi.org/10.1002/pbc.21349 doi:10.1002/ pbc. 21349

4. Castro PF. Transplante de células-tronco hematopoéticas em pediatria. In: Gato MIR, coordinator. Transplante de células-tronco hematopoéticas: Introdução para farmacêuticos. São Paulo: Publishing company Segmento Farma; 2018. p. 57-63.

5. Sassen SDT, Zwaan CM, Sluis IMVD, Mathôt RAA. Pharmacokinetics and population pharmacokinetic in pediatric oncology. Pediatric Blood and Cancer [Internet]. 2020 [cited 2021 Jun 9];67(4): e28132. Avaiable from: https://doi.org/10.1002/ pbc.28132 doi: $10.1002 /$ pbc.28132

6. Vassal G, Fischer A, Challine D, et al. Busulfan disposition below the age of three: alteration in children with lysosomal storage disease. Blood. 1993;82:1030-1034

7. Slattery JT, Sanders JE, Buckner CD, et al. Graft-rejection and toxicity following bone marrow transplantation in relation to busulfan pharmacokinetics. Bone Marrow Transplant. 1995;16:3142.

8. Bragalone DL. Drug information handbook for oncology. A complete guide to combination chemotherapy regimens. Ohio: Lexi-Comp Inc; 2014. p. 507-509; 519-521; 741-743; 801-803; 1203-1205; 1830-1832.

9. Reiss U, Cowan M, McMillan A, Horn B. Hepatic venoocclusive disease in blood and bone marrow transplantation in children and young adults: incidence, risk factors, and outcome in a cohort of 241 patients. J Pediatr Hematol Oncol. 2002 Dec;24(9):746-50. doi: 10.1097/00043426200212000-00013. PMID: 12468917.

10. Peters WP, Stuart A, Klotman M, et al. High-dose combination cyclophosphamide, cisplatin, and melphalan with autologous bone marrow support. A clinical and pharmacologic study. Cancer Chemother Pharmacol. 1989;23:377-383.

11. Klein NW, Vogler MA, Chatot CL, et al. The use of cultured rat embryos to evaluate the teratogenic activity of serum: cadmium and cyclophosphamide. Teratology. 1980;21:199-208.

12. Jardine I, Fenselau C, Appler M, et al. Quantitation by gas chromatography-chemical ionization mass spectrometry of cyclophosphamide, phosphoramide mustard, and nornitrogen mustard in the plasma and urine of patients receiving cyclophosphamide therapy. Cancer Res. 1978;38: 408-415.

13. Reis NA, Tofani A, Santos CF, Morassi CV, Costa DCR, Ito FT, Gato MIR, Castro PF, Villa PR, Macedo RS. Transplante de células-tronco hematopoéticas: Introdução para farmacêuticos. São Paulo: Publishing company Segmento Farma. 70 p.

14. Gerson, SL; Weeks, LD; Chabner, BA. Alkylating and Methylating Agents. In: Chabner, BA; Longo, DL - Cancer Chemotherapy, Immunotherapy and Biotherapy - Principles and Practice. 6th edition. Philadelphia: Wolters Kluwer; 2019.

15. Lexi-drugs online [database on the Internet]. Hudson (OH): Lexicomp, Inc.; 2021. Available from: http://online.lexi.com. Subscription required to view.

16. Worden, FP; Perissinotti, AJ; Marini, BL. Cancer Pharmacology and Pharmacotherapy Review Study Guide for Oncology Boards and MOC Exams. 1st ed. New York: Demos Medical, 2016.

17. BC Cancer Agency Cancer Drug Manual. Methotrexate. August 2017. Available from: http:// www.bccancer.bc.ca/drug-database-site/ Drug\%20Index/Methotrexate_monograph.pdf

18. Methotrexato In: Drug Ref [database on the Internet]. Greenwood Village (CO): IBM Corporation; 2021. Available from: www.micromedexsolutions.com. Subscription required to view.

19. Macedo RS, Junior WR, Martins JS. Farmácia Clínica em Oncologia. $1^{\text {a }}$ ed. São Paulo: Farmacêutica, 2021. p. 391. 
20. Paul J. Hesketh, Mark G. Kris, Ethan Basch, Kari Bohlke, Sally Y. Barbour, Rebecca Anne ClarkSnow, et al. Antiemetics: ASCO Guideline Update. Journal of Clinical Oncology 2020 38:24, 2782-2797. Availabre from: https://ascopubs. org/doi/full/10.1200/JCO.20.01296.

21. BC Cancer Agency Cancer Drug Manual. Cytarabine. May 2014. Available from: http://www. bccancer.bc.ca/drug-database-site/Drug\%20 Index/Cytarabine_monograph_1May2014.pdf

22. BC Cancer Agency Cancer Drug Manual. Fludarabine. September 2013. Available from: http://www.bccancer.bc.ca/drug-database-site/Drug\%20Index/Fludarabine_ monograph_1Sept2013_formatted.pdf

23. Fludarabine. In: Drug Ref [database on the Internet]. Greenwood Village (CO): IBM Corporation; 2021. Available from: www.micromedexsolutions.com. Subscription required to view.

24. BC Cancer Agency Cancer Drug Manual. Etoposide. March 2020. Available from: http://www. bccancer.bc.ca/drug-database-site/Drug\%20Index/Etoposide_monograph.pdf

25. VISWANATHAN, Srinivas; CHEN, Yi-Bin. Imunologia do Transplante de Células-Tronco Hematopoiéticas. In: CHABNER, Bruce A; LONGO, Dan L. Manual de Oncologia de Harrison.2 $2^{\text {a }}$ ed. Porto Alegre: AMGH; 2015. p. 475-85.

26. Etoposide. In: Drug Ref [database on the Internet]. Greenwood Village (CO): IBM Corporation; 2021. Available from: www.micromedexsolutions.com. Subscription required to view.

27. Fauldmetro ${ }^{\circledR}$ [package insert]. São Paulo: Libbs Farmacêutica Ltda; 2019 [cited 2021 Jun 11]. Available from: https://www.libbs.com.br/ wp-content/uploads/2015/12/Fauldmetro_ Bula_Profissional-1.pdf

28. Faulcita ${ }^{\circledR}$ [package insert]. São Paulo: Libbs Farmacêutica Ltda; 2015 [cited 2021 Jun 11]. Available from: https://www.libbs.com.br/ wp-content/uploads/2015/12/Fauldcita_Profissional_V11-ampliada.pdf
29. Fludalibbs ${ }^{\oplus}$ [package insert]. São Paulo: Libbs Farmacêutica Ltda; 2021 [cited 2021 Jun 11]. Available from:https://www.libbs.com.br/ wp-content/uploads/2015/12/Fludalibbs_ Profissional_V12-20-ampliada-1.pdf

30. Eunades $\mathrm{CS}^{\oplus}$ [package insert]. São Paulo: Wyeth Indústria Farmacêutica Ltda; 2019 [cited 2021 Jun 11]. Available from Available from: https://buladeremedio.net/pdfs/eunades_ Cs_11040892019_11602963-repaired.pdf

31. Frampton, JE; Wagstaff, AJ. Alemtuzumab. Drugs, 2003: 63(12); 1229-1243.

32. Nishihori, T; Al Khadimi, Z; Hamadani, M; Kharfan-Dabaja, MA. Anthymocyte globulin in allogeneic hemtopoietic cell transplantation: benefits and limitations. Immunotherapy 2016: 8(4); 435-447.

33. Mohty, M. Mechanisms of action of anthymocyte globulin: T-cell depletion and beyond. Leukemia 2007: 21; 1387-1394.

34. Seidel MG; Fritsch G; Matthes-Martin S. Lawitschka, A; Lion, T; Pötschger, $U$ et al. Antithymocyte globulin pharmacokinetics in pediatric patients after hematopoietic stem cell transplantation. Journal of Pediatric Hematology Oncology 2005: 27(10); 532-536.

35. Jol-Van Der Zijde CM, Bredius RG, Jansen-Hoogendijk AM et al. IGG antibodies to ATG early after pediatric hematopoietic SCT increase the risk of acute GVHD. Bone Marrow Transplantation (2012): 47(3); 360-368.

36. Lyman, GH, Kuderer, NM. Hematopoietic Growth Factors. In: Chabner, BA; Longo, DL Cancer Chemotherapy, Immunotherapy and Biotherapy - Principles and Practice. 6th edition. Philadelphia: Wolters Kluwer; 2019.

37. Stabilis Database. INFOSTAB Association [Internet]. [cited 2021, June 11th]. Available from: https://www.stabilis.org/Monographie.php?ldMolecule $=948$ 